\title{
COCCOSTOID ARTHRODIRE PROTITANICHTHYS FROM THE MIDDLE DEVONIAN PLUM BROOK SHALE OF NORTH CENTRAL OHIO
}

KAMPOURIS*, George E., 2354 Kenwood Blvd., Toledo, OH 43606, U.S.A.; SIBILA, Daniel, Dept. of Geology, University of Toledo, Toledo, OH 43606, U.S.A.; CAMP, Mark J., Dept. of Geology, University of Toledo, Toledo, OH 43606, U.S.A.

A number of plates from one individual coccostoid arthrodire assigned to the genus Protitanichthys have been found at the type locality of the Middle Devonian Plum Brook Shale on the NASA Plumbrook Station in Erie Co., Ohio.

Research at this site involved the reexamination of those units described by Stauffer (1916) and Stumm (1939). Systematic sampling of Stumm's zone 'C' yielded a number of dermal bone fragments and subsequent quarrying uncovered a concentration of complete plates which were reassembled and cleaned at the Vertebrate Paleontology Dept., Cleveland Museum of Natural History, Cleveland, Ohio.

Specimens include the following plates: right anterior dorsal lateral, right suborbital, interolateral, internasal, anterior and posterior median ventral, right and left posterior ventrolaterals, as well as inferognathal and supragnathal elements. Preservation of surface detail of this material including tuberculation, sensory lines, articular grooves, overlaps and laminae is exceptional.

All plates appear to belong to one individual, probably a young adult estimated at a metre in length. Two of these plates, the internasal and anterior median ventral, have not been previously described. The remainder are identical to isolated specimens found in the Silica Shale of Sylvania, Ohio which has been correlated in age with the Plum Brook.

The fauna of the upper Plum Brook is typically Hamilton and can be correlated by index fossil communities to similar strata in the Arkona, Silica, Traverse, Olentangy and Hamilton Formations.

Zone ' $\mathrm{C}$ ' of the Plum Brook is a gradual 1.5 metre transition sequence of soft blue shales between the $25 \mathrm{~cm}$ ' $\mathrm{B}$ ' and ' $\mathrm{D}$ ' limestone bands and is marked by three hiatus events and one layer of nodular concretions. Fossils are concentrated in two $7 \mathrm{~cm}$, iron-rich bands of invertebrate debris, a $10 \mathrm{~cm}$ layer of unreworked brachiopod hash and $20 \mathrm{~cm}$ of platey shale containing Protitanichthys followed by $20 \mathrm{~cm}$ of hard shale at base representing a distinct Orthoceras zone.

Both Stauffer and Stumm reported only token invertebrate fauna from this unit which was covered at the time of their investigations. It is likely that material from zone ' $\mathrm{C}$ ' was collected at surface and assigned by both scholars to other units.

Fauna directly associated with the Protitanichthys assembly include pyritized Orthoceras, Phacops rana paucituberculata, and Devonochonetes as well as a variety of microfossils concentrated around and encrusting the plates.

Type specimens of Protitanichthys rockportensis from the Traverse Group of Michigan consist of a skull roof and some dorsal thoracic plates. Many arthrodire plates from the Silica Shale have been assigned to the coccostoidea and only tentatively referred to Protitanichthys. The main body of this material consists of isolated individual specimens from indeterminate units making generic reference uncertain. Similarly, $P$. fossatus from the Delaware Limestone of Central Ohio is represented by one cranial roof plate while other material from this formation remains unassigned.

This Protitanichthys specimen from the Plum Brook Shale will contribute to resolving the generic affinity of a wide body of curated but unidentified material. 